\title{
Cold Hardiness and the Effects of a Low-input Regime on 15 Tall, Warm-season, Native and Ornamental Grasses in the Upper Midwestern United States
}

\author{
Alan Zuk ${ }^{1}$, Qi Zhang, Ted Helms, and Harlene Hatterman-Valenti
}

AdDitional InDEX wORDs. Andropogon, Miscanthus, Saccharum, drought tolerance, winter survival

SUMMARY. Fifteen tall, warm-season, native and ornamental grasses were subjected to a 3-year, low-input, and cold hardiness trial conducted from 2010 to 2013 in zone 4a at Fargo and Mandan, ND. Grasses tested were big bluestem [species (Andropogon gerardii)], 'Pawnee' big bluestem ( $A$. gevardii), silver banner grass (Miscanthus sacchariflorus), giant miscanthus (Miscanthus $\times$ giganteus), hardy pampas grass, (Saccharum ravennae), and the following maidengrass (Miscanthus sinensis) cultivars: Silver Feather, Narrow Leaf, Blondo, Autumn Light, Condensatus, Grosse Fontaine, Morning Light, Gracillimus, Strictus, and Zebrinus. In addition to survival, the grasses were also rated for spring vigor and fall quality (010 scale for both evaluations), fall leaf length, and fall flower height. The grasses received no management during the trial other than irrigation during the first season and weed control. The grasses were exposed to subsurface soil temperatures (at 6-inch depth) that reached as low as $-8.6^{\circ} \mathrm{C}$ at the Fargo location and $-6{ }^{\circ} \mathrm{C}$ at the Mandan location. The study revealed that all big bluestem (species), 'Pawnee' big bluestem, and silver banner grass survived at both locations; silver banner grass scored the highest spring vigor ratings; silver banner grass and 'Pawnee' big bluestem scored the highest fall quality ratings; silver banner grass produced the longest fall leaf length; and 'Pawnee' big bluestem, big bluestem (species), and silver banner grass produced the tallest fall flowers.

$\mathrm{M}$ any native and ornamental grasses can provide yearlong beauty and interest including autumn and winter (Plowes, 2012 ) to residential, business, municipal, and natural landscapes. They can be used as specimen plants; accent plants; or for groupings, screening, and massing in parks and on golf courses; and even in problematic areas to reduce management requirements and operating expenses. The dried leaves, stalks, and inflorescences of tall and medium-height grasses can provide value to the winter landscape by creating rustling sounds in the wind and by attracting birds (Kalb, 2009), if they are not completely covered by snow. Tall grasses are defined as those

Department of Plant Sciences, North Dakota State University, Fargo, ND 58108

We extend our gratitude to the NDSU Developmental Foundation for funding this research with an Ozbun Economic Development grant received in Apr. 2010 (Project no. FAR0016965).

We are also grateful to Mary Kay Tokach for helping us maintain the test plot in Mandan, ND. Her assistance and knowledge of ornamental grasses was invaluable

${ }^{1}$ Corresponding author. E-mail: alan.zuk@ndsu.edu. doi: 10.21273/HORTTECH03455-16 that grow higher than $5 \mathrm{ft}$; the height of medium-sized grasses ranges from 2 to $5 \mathrm{ft}$, and short grasses are less than $2 \mathrm{ft}$ (Love, 2012; Love and Salaiz, 2009).

If the correct grass species is selected, native and ornamental grasses can thrive in adverse growing conditions ranging from hot to cold air temperatures, dry to wet soil conditions, alkaline to acidic soils, nutrient-deficient and saline soils, and even among competing vegetation (Greenlee and Fell, 1992; Koppler et al., 2014). Some grasses will tolerate light to moderate shade (Wilson, 2011). Most native and ornamental grasses are susceptible to few insect or disease problems which reduces the need for pesticide inputs (Fech et al.,
2007). The extensive root system of most warm-season grasses allows the plants to extract water from a larger soil profile (drought avoidance); cool-season ornamental grasses routinely go dormant during hot or dry periods. When adequate moisture and favorable growing conditions return, the apical meristem begins to produce new leaves (drought tolerance) (Fry and Huang, 2004). These grasses are often used in landscapes in communities that routinely implement watering restrictions during the summer months.

Residents and landscape managers in the upper midwestern United States frequently rely on extension service information provided by the University of Minnesota (Meyer et al., 2008 ) to select cold-hardy grass species. There is a need for more research that addresses the survivability of native and ornamental grasses in the diverse soil and environmental growing conditions found throughout the upper midwestern United States. Some grasses have the ability to survive in U.S. Department of Agriculture (USDA) climate zones lower than the zone in which they are listed and some should be reevaluated for cold hardiness. Silver banner grass, an extremely cold-hardy species, is typically listed as a grass that can survive in zones 4 to 5 (Greenlee and Fell, 1992; Kurt Bluemel, Inc., 2015). However, researchers at the University of Minnesota found that silver banner grass has the ability to survive in USDA zone 2 (Meyer, 2012). Some grasses may be more widely accepted by nursery professionals and gardeners in the upper midwestern United States, if it can be proven that they are cold hardy enough to survive in zone 4 and also perform at an acceptable level under a low-input regime.

The objective of this study was to determine the cold hardiness and survivability of 15 tall, warm-season, native and ornamental grasses planted

\begin{tabular}{llll}
\hline $\begin{array}{l}\text { Units } \\
\begin{array}{l}\text { To convert U.S. to SI, } \\
\text { multiply by }\end{array}\end{array}$ & U.S. unit & SI unit & $\begin{array}{l}\text { To convert SI to U.S., } \\
\text { multiply by }\end{array}$ \\
\hline 7.8125 & $\mathrm{fl} \mathrm{oz} / \mathrm{gal}$ & $\mathrm{mL} \cdot \mathrm{L}^{-1}$ & 0.1280 \\
0.3048 & $\mathrm{ft}$ & $\mathrm{m}$ & 3.2808 \\
3.7854 & gal & $\mathrm{L}$ & 0.2642 \\
2.54 & inch(es) & $\mathrm{cm}$ & 0.3937 \\
25.4 & inch(es) & $\mathrm{mm}$ & 0.0394 \\
$\left({ }^{\circ} \mathrm{F}-32\right) \div 1.8$ & ${ }^{\circ} \mathrm{F}$ & ${ }^{\circ} \mathrm{C}$ & $\left({ }^{\circ} \mathrm{C} \times 1.8\right)+32$
\end{tabular}


Table 1. Number of tall grasses that survived the winter month of 2010-11, 2011-12, and 2012-13 at Fargo and Mandan, ND. ${ }^{\mathrm{z}}$

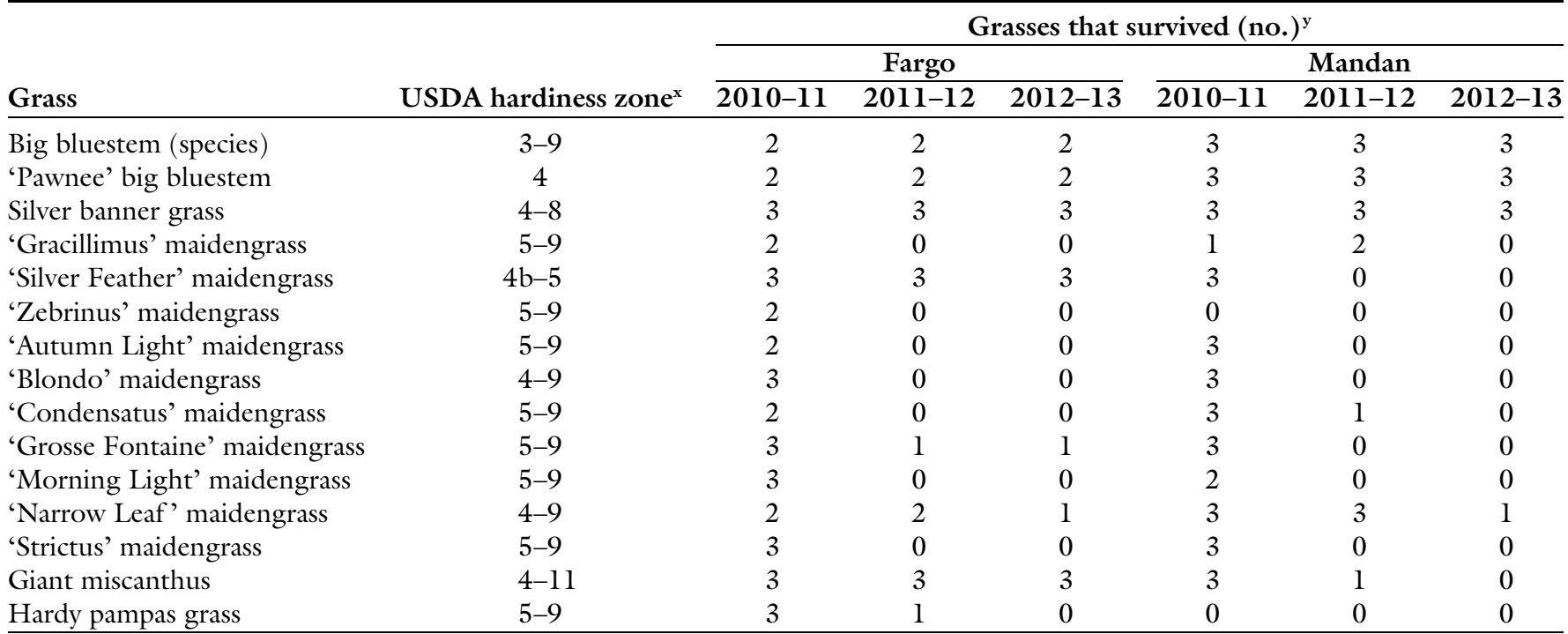

${ }^{\mathrm{z}}$ Grasses were planted on 21 June and 1 July 2010 at Fargo and Mandan, respectively.

${ }^{\text {y }}$ urvival numbers were based on three replications of each grass; evaluations were taken after spring green up.

${ }^{\mathrm{x}}$ USDA hardiness zone information (Bluebird Nursery, 2015; Kurt Bluemel, Inc., 2015; Missouri Botanical Garden, 2015; Wilson, 2011).

in fully exposed sites at Fargo and Mandan, ND, and managed under a low-input regime for 3 years.

\section{Materials and methods}

On 21 June 2010, 15 tall, warm-season, native and ornamental grasses were planted from 1-gal containers to a fully exposed site on the North Dakota State University campus at Fargo (lat. $46^{\circ} 53^{\prime} 31^{\prime \prime} \mathrm{N}$, long. $96^{\circ} 48^{\prime} 46^{\prime \prime} \mathrm{W}$ ) and on 1 July 2010 at the USDA, Agricultural Research Service Northern Great Plains Research Laboratory in Mandan, ND (lat. $46^{\circ} 48^{\prime} 40^{\prime \prime} \mathrm{N}$, long. $\left.100^{\circ} 54^{\prime} 50^{\prime \prime} \mathrm{W}\right)$. The plants were arranged in a complete randomized block design with three replications of each grass. The grasses were spaced $8 \mathrm{ft}$ apart within each row and $8 \mathrm{ft}$ between rows.

The germplasm sources of the grasses evaluated in this trial originated from Germany, New Jersey, Nebraska, and Wisconsin.

The soils at the Fargo site are described as a Fargo silty clay [fine, smectitic, frigid Typic Epiaquerts (USDA, 2015)] with a $\mathrm{pH}$ of 8.1. The soils at the Mandan site are described as a Tally-Parshall complex (coarse-loamy, mixed, superactive, frigid Typic Haplustolls), fine sandy loam (USDA, 1998a, 1998b), and a Telfer (sandy, mixed, frigid Entic Haplustolls) loamy fine sand (USDA, 1999) with a $\mathrm{pH}$ of 7.0.

Table 2. Spring vigor of $\mathbf{1 5}$ ornamental grass species and cultivars in response to a species $\times$ location interaction imposed on grasses grown at Fargo and Mandan, ND. ${ }^{x}$

\begin{tabular}{lccc}
\hline & \multicolumn{3}{c}{ Spring vigor (0-10 scale) } \\
\cline { 2 - 4 } Grass & Fargo & Mandan & Avg \\
\hline Silver banner grass & 10.0 & 9.2 & $9.6 \mathrm{a}^{\mathrm{y}}$ \\
'Pawnee' big bluestem & 6.3 & 9.5 & $7.9 \mathrm{~b}$ \\
Big bluestem (species) & 5.0 & 10.0 & $7.5 \mathrm{~b}$ \\
'Silver Feather' maidengrass & 2.7 & 0.0 & $1.4 \mathrm{c}$ \\
'Blondo' maidengrass & 1.8 & 0.0 & $0.9 \mathrm{c}$ \\
'Narrow Leaf' maidengrass & 0.8 & 0.8 & $0.8 \mathrm{c}$ \\
Giant miscanthus & 1.3 & 0.0 & $0.7 \mathrm{c}$ \\
Hardy pampas grass & 0.7 & 0.0 & $0.4 \mathrm{c}$ \\
'Grosse Fontaine' maidengrass & 0.7 & 0.0 & $0.4 \mathrm{c}$ \\
'Condensatus' maidengrass & 0.0 & 0.2 & $0.1 \mathrm{c}$ \\
'Morning Light' maidengrass & 0.0 & 0.0 & $0.0 \mathrm{c}$ \\
'Gracillimus' maidengrass & 0.0 & 0.0 & $0.0 \mathrm{c}$ \\
'Autumn Light' maidengrass & 0.0 & 0.0 & $0.0 \mathrm{c}$ \\
'Zebrinus' maidengrass & 0.0 & 0.0 & $0.0 \mathrm{c}$ \\
'Strictus' maidengrass & 0.0 & 0.0 & $0.0 \mathrm{c}$ \\
\hline
\end{tabular}

${ }^{\mathrm{z}}$ Grasses were planted on 21 June and 1 July 2010 at Fargo and Mandan, respectively.

${ }^{y}$ Spring vigor ratings were taken in May or June in $2012-13 ; 0=$ dead, 1 = poorest, $6=$ generally acceptable, $10=$ perfect/ideal.

${ }^{\mathrm{x}}$ Means of three replicates; numbers in a column followed by the same letter are not significantly different according to Duncan's multiple range test at $P=0.05$.

Immediately after planting, the grasses were irrigated via drip irrigation. The drip system was assembled with 16-mm polyethylene tubing (part no. XFDl00; Rain Bird Corp., Azusa, CA) that ran the length of each 120-ft row. Emitters (part no. XBO5PC, Rain Bird Corp.) were inserted into the pipe at the base of each plant to provide water at $0.5 \mathrm{gal} / \mathrm{h}$. Each plant received 1 gal of water daily for the first 4 weeks after planting and then was irrigated only to prevent stress during the remainder of the growing season. Grass stress was evaluated by looking for the first signs of leaf rolling (wilting). No artificial irrigation was provided after the first season.

A 4-inch layer of spring wheat (Triticum aestivum) straw was applied between rows at the Fargo site 
on 19 Aug. and at the Mandan site on 23 Aug. to prevent water loss and reduce weed establishment during the first season. Straw mulch was not reapplied after the first application decayed. Wheat straw can inhibit the growth of weeds (Bertholdsson, 2005; Hamdi et al., 2001; Nakano et al., 2006). However, no published evidence could be found that cites an allelopathic effect on the grasses observed in this study. Initially, weeds were controlled by a combination of spot treating with glyphosate at $2 \mathrm{fl}$ $\mathrm{oz} / \mathrm{gal}$ and physical removal with a hoe or by pulling by hand. After the first year, grassy and broadleaf weeds in close proximity to plants were pulled by hand, whereas weeds between plant rows were controlled by mowing.

Soil surface and subsurface temperatures were recorded in the fall and winter with wireless Lascar data loggers (model no. EL-USB-1; Lascar Electronics, Salisbury, UK) that were placed on the soil surface within a row of grasses at the north and south perimeter and the center of the trial. By Nov. 2010, most of the straw mulch had blown away or decayed with only remnants remaining on the soil surface; thus it should not have affected the soil surface temperatures. Each surface sensor was anchored in place with a 4 -inch landscape staple. Sensors were also buried 6 inches below the soil surface in close proximity to each surface sensor to record the subsurface soil temperatures. The sensors were removed and data retrieved each spring after the grasses broke dormancy. Air temperatures at both sites were provided throughout each growing season by the North Dakota Agricultural Weather Network (NDAWN, 2015).

An assessment of winter survival was taken in mid-to-late spring in 2010-13 after the grasses broke dormancy. Nonsurviving plants could be accurately counted at that time. Spring vigor ratings were also taken at the same time in 2012-13 and were based on the amount of relative biomass produced. Plant vigor ratings were based on a scale of continuous integers ranging from 0 to 10 , where 0 = dead, 1 = slightly detectable living biomass, $6=$ moderate amount of living biomass, and $10=$ abundant living biomass. Fall quality ratings were taken in Oct. in 2012-13 and

Table 3. Fall quality of 15 ornamental grasses in response to a grass $\times$ location interaction imposed on grasses grown in Fargo and Mandan, ND. ${ }^{\mathrm{z}}$

\begin{tabular}{lccc}
\hline & \multicolumn{3}{c}{ Fall quality (0-10 scale) $^{\mathrm{y}}$} \\
\cline { 2 - 4 } Grass & Fargo & Mandan & Avg \\
\hline Silver banner grass & 5.3 & 5.7 & $5.5 \mathrm{a}^{\mathrm{x}}$ \\
'Pawnee' big bluestem & 3.8 & 6.5 & $5.2 \mathrm{a}$ \\
Big bluestem (species) & 2.7 & 5.7 & $4.2 \mathrm{~b}$ \\
Giant miscanthus & 3.0 & 0.0 & $1.5 \mathrm{c}$ \\
'Silver Feather' maidengrass & 2.5 & 0.0 & $1.3 \mathrm{c}$ \\
'Narrow Leaf' maidengrass & 1.5 & 0.5 & $1.0 \mathrm{~cd}$ \\
'Blondo' maidengrass & 1.7 & 0.0 & $0.8 \mathrm{~cd}$ \\
'Grosse Fontaine' maidengrass & 0.3 & 0.0 & $0.2 \mathrm{~d}$ \\
'Autumn Light' maidengrass & 0.0 & 0.0 & $0.0 \mathrm{~d}$ \\
'Morning Light' maidengrass & 0.0 & 0.0 & $0.0 \mathrm{~d}$ \\
Hardy pampas grass & 0.0 & 0.0 & $0.0 \mathrm{~d}$ \\
'Gracillimus' maidengrass & 0.0 & 0.0 & $0.0 \mathrm{~d}$ \\
'Strictus' maidengrass & 0.0 & 0.0 & $0.0 \mathrm{~d}$ \\
'Zebrinus' maidengrass & 0.0 & 0.0 & $0.0 \mathrm{~d}$ \\
'Condensatus' maidengrass & 0.0 & 0.0 & $0.0 \mathrm{~d}$ \\
\hline
\end{tabular}

${ }^{\mathrm{z}}$ Grasses were planted on 21 June and 1 July 2010 at Fargo and Mandan, respectively.

${ }^{y}$ Fall quality ratings were taken in Oct. $2012-13 ; 0=$ dead, $1=$ poorest, $6=$ generally acceptable, $10=$ perfect $/$ ideal. ${ }^{x}$ Means of three replicates; numbers in a column followed by the same letter are not significantly different according to Duncan's multiple range test at $P=0.05$.

Table 4. Fall leaf length of 15 ornamental grasses in response to a grass $\times$ location interaction imposed on grasses grown in Fargo and Mandan, ND. ${ }^{\mathrm{z}}$

\begin{tabular}{lrcc}
\hline & \multicolumn{3}{c}{ Fall leaf length $(\mathbf{c m})^{\mathrm{y}}$} \\
\cline { 2 - 4 } Grass & Fargo & Mandan & Avg \\
\hline Silver banner grass & 133.0 & 105.0 & $119.0 \mathrm{a}$ x \\
'Pawnee' big bluestem & 71.0 & 108.0 & $90.0 \mathrm{~b}$ \\
Giant miscanthus & 160.0 & 0.0 & $80 \mathrm{bc}$ \\
Big bluestem (species) & 67.0 & 74.0 & $71.0 \mathrm{~cd}$ \\
'Silver Feather' maidengrass & 109.0 & 0.0 & $55.0 \mathrm{~d}$ \\
'Blondo' maidengrass & 58.0 & 0.0 & $29.0 \mathrm{e}$ \\
'Narrow Leaf' maidengrass & 32.0 & 13.0 & $23.0 \mathrm{e}$ \\
'Grosse Fontaine' maidengrass & 27.0 & 0.0 & $14.0 \mathrm{ef}$ \\
'Autumn Light' maidengrass & 0.0 & 0.0 & $0.0 \mathrm{f}$ \\
'Morning Light' maidengrass & 0.0 & 0.0 & $0.0 \mathrm{f}$ \\
Hardy pampas grass & 0.0 & 0.0 & $0.0 \mathrm{f}$ \\
'Gracillimus' maidengrass & 0.0 & 0.0 & $0.0 \mathrm{f}$ \\
'Strictus' maidengrass & 0.0 & 0.0 & $0.0 \mathrm{f}$ \\
'Zebrinus' maidengrass & 0.0 & 0.0 & $0.0 \mathrm{f}$ \\
'Condensatus' maidengrass & 0.0 & 0.0 & $0.0 \mathrm{f}$ \\
\hline 'Grass
\end{tabular}

${ }^{\mathrm{z}}$ Grasses were planted on 21 June and 1 July 2010 at Fargo and Mandan, respectively.

${ }^{y}$ Fall leaf length was measured to the closest centimeter in Oct. 2012-13; the longest leaf was artificially extended vertically to its maximum length before measuring; $1 \mathrm{~cm}=0.3937$ inch.

${ }^{\mathrm{x}}$ Means of three replicates; numbers in a column followed by the same letter are not significantly different according to Duncan's multiple range test at $P=0.05$.

were based on a combination of color, density, uniformity, texture, disease, and environmental stress (Morris and Shearman, 2006). Plant quality was also based on continuous scale ranging from 0 to 10 where $0=$ dead, $1=$ poorest, $6=$ generally acceptable, and $10=$ perfect $/$ ideal . The term "acceptable" used in any of the rating scales in this study is an indication that the grass is suitable to be used as a landscape plant. To determine leaf length and flower height, the longest leaf and tallest flower of each plant were measured (in Oct. 2012-13) to the closest centimeter from the soil surface to the tip of the leaf or flower. The longest leaf was artificially extended vertically to its maximum length before measuring. Leaf length, flower height, vigor, and quality measurements in 2010-2011 were variable. Therefore, the authors considered 
that period an establishment phase and the data were not provided.

The analysis of variance procedure in SAS (version 9.3; SAS Institute, Cary, NC) was used to test for treatment effects. Means were separated by Duncan's multiple range test when a significant $(P \leq 0.05)$ difference occurred. Mean squares were equated to expected mean squares to determine the proper $\mathrm{F}$ tests and the Satterthwaite procedure (Carmer et al., 1989) was used to synthesize mean squares when necessary. Since years and locations were both considered random effects, the best estimate of each treatment effect was the mean, averaged across locations and years (Moore and Dixon, 2015). The mean of each treatment in the two locations is provided to show whether the treatment effects were consistent across locations (McIntosh, 2015). Genotype was considered a fixed effect while year, location, and replication were considered random effects.

Survival was measured as the number of replicates with surviving plants divided by the total number of replicates. Since the numerator of the proportion (survival score) represents the number of replicates with surviving plants, it was not possible to conduct the analysis of variance on the survival score and for this reason the associated Duncan's multiple range comparisons cannot be reported.

\section{Results and discussion}

Plant survival. By the conclusion of the field trial at the Fargo location in Oct. 2013, all replicates of silver banner grass, 'Silver Feather' maidengrass, and giant miscanthus were still alive. Two of the big bluestem (species) and 'Pawnee' big bluestem replicates survived as did only one replicate of 'Grosse Fontaine' maidengrass and 'Narrow Leaf' maidengrass. Each replicate of the following maidengrass cultivars were dead: Gracillimus, Zebrinus, Autumn Light, Blondo, Condensatus, Morning Light, and Strictus, in addition to all hardy pampas grass replicates (Table 1). For reasons stated in "Materials and Methods," an analysis of variance on survival could not be provided.

By the conclusion of the Mandan trial, all big bluestem (species), 'Pawnee' big bluestem, and silver banner grass replicates survived and only one
Table 5. Fall flower height of 15 ornamental grasses in response to a grass $\times$ location interaction imposed on grasses grown in Fargo and Mandan, ND. ${ }^{\mathrm{z}}$

\begin{tabular}{lrrr}
\hline & \multicolumn{3}{c}{ Fall flower ht $(\mathbf{c m})^{\mathbf{y}}$} \\
\cline { 2 - 4 } Grass & Fargo & Mandan & Avg \\
\hline 'Pawnee' big bluestem & $93.0^{\mathrm{x}}$ & 173.0 & $133.0 \mathrm{a}$ x \\
Big bluestem (species) & 95.0 & 160.0 & $128.0 \mathrm{a}$ \\
Silver banner grass & 99.0 & 151.0 & $125.0 \mathrm{a}$ \\
'Silver Feather' maidengrass & 113.0 & 0.0 & $57.0 \mathrm{~b}$ \\
'Narrow Leaf' maidengrass & 50.0 & 15.0 & $33.0 \mathrm{c}$ \\
'Blondo' maidengrass & 54.0 & 0.0 & $27.0 \mathrm{c}$ \\
'Autumn Light' maidengrass & 0.0 & 0.0 & $0.0 \mathrm{~d}$ \\
'Condensatus' maidengrass & 0.0 & 0.0 & $0.0 \mathrm{~d}$ \\
'Grosse Fontaine' maidengrass & 0.0 & 0.0 & $0.0 \mathrm{~d}$ \\
'Morning Light' maidengrass & 0.0 & 0.0 & $0.0 \mathrm{~d}$ \\
Hardy pampas grass & 0.0 & 0.0 & $0.0 \mathrm{~d}$ \\
'Gracillimus' maidengrass & 0.0 & 0.0 & $0.0 \mathrm{~d}$ \\
'Strictus' maidengrass & 0.0 & 0.0 & $0.0 \mathrm{~d}$ \\
'Zebrinus' maidengrass & 0.0 & 0.0 & $0.0 \mathrm{~d}$ \\
Giant miscanthus & 0.0 & 0.0 & $0.0 \mathrm{~d}$ \\
\hline
\end{tabular}

${ }^{\mathrm{z}}$ Grasses were planted on 21 June and 1 July 2010 at Fargo and Mandan, respectively.

${ }^{y_{y}}$ Fall flower height was measured to the closest centimeter in Oct. $2012-13 ; 1 \mathrm{~cm}=0.3937$ inch.

${ }^{\mathrm{x}}$ Means of three replicates; numbers in a column followed by the same letter are not significantly different according to Duncan's multiple range test at $P=0.05$.
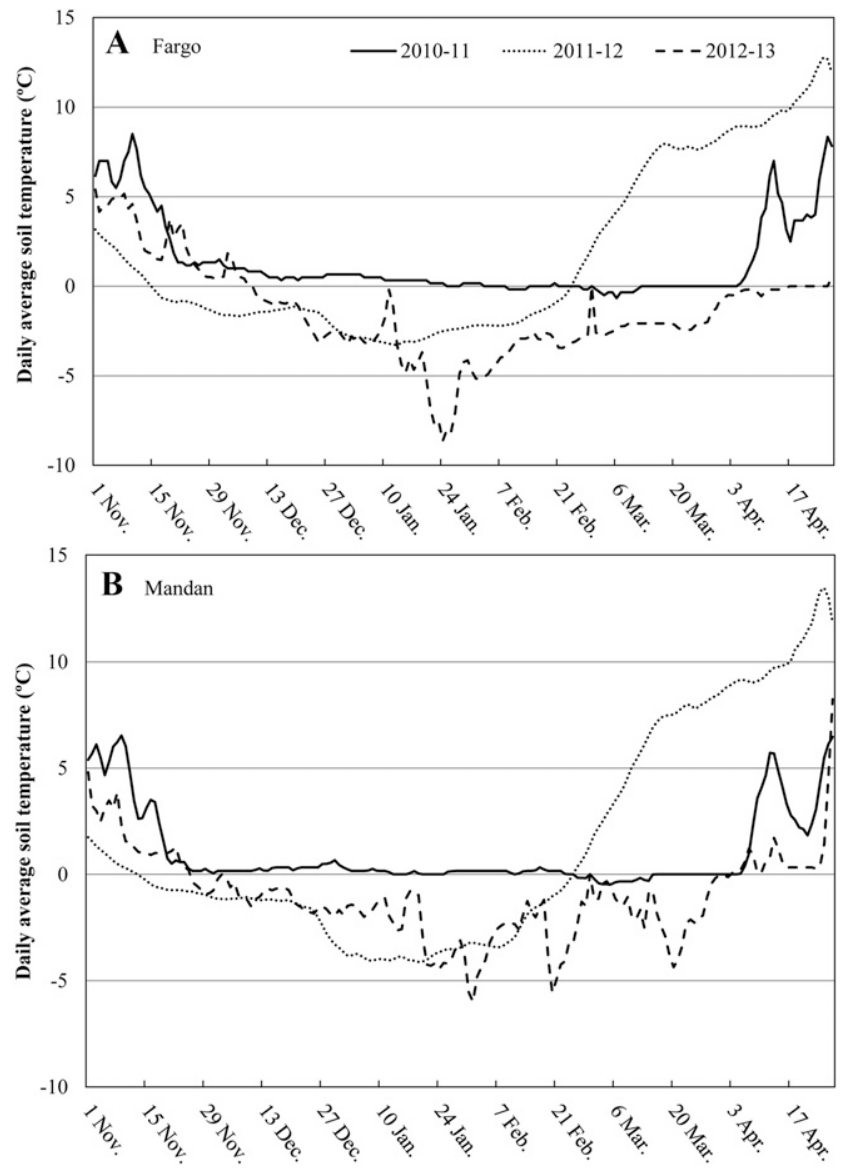

Fig. 1. Daily average soil temperature at 6 -inch $(15.2 \mathrm{~cm})$ depth from Nov. to Apr. 2010-13 at (A) Fargo, ND and (B) Mandan, ND. Subsurface temperatures were recorded with data loggers (model no. EL-USB-1; Lascar Electronics, Salisbury, $\mathrm{UK}) ;\left(1.8 \times{ }^{\circ} \mathrm{C}\right)+32={ }^{\circ} \mathrm{F}$. 
'Narrow Leaf' maidengrass replicate survived. The eight grasses that had a $100 \%$ mortality rate at the Fargo location also died at the Mandan site in addition to 'Silver Feather' and 'Grosse Fontaine' maidengrass and giant miscanthus (Table 1).
SPRING VIGor. A significant $(P \leq$ $0.05)$ grass $\times$ location interaction was observed in spring vigor between the Fargo and Mandan sites (Table 2). Although there was a change in rank with silver banner grass, it had an acceptable level of vigor at Fargo
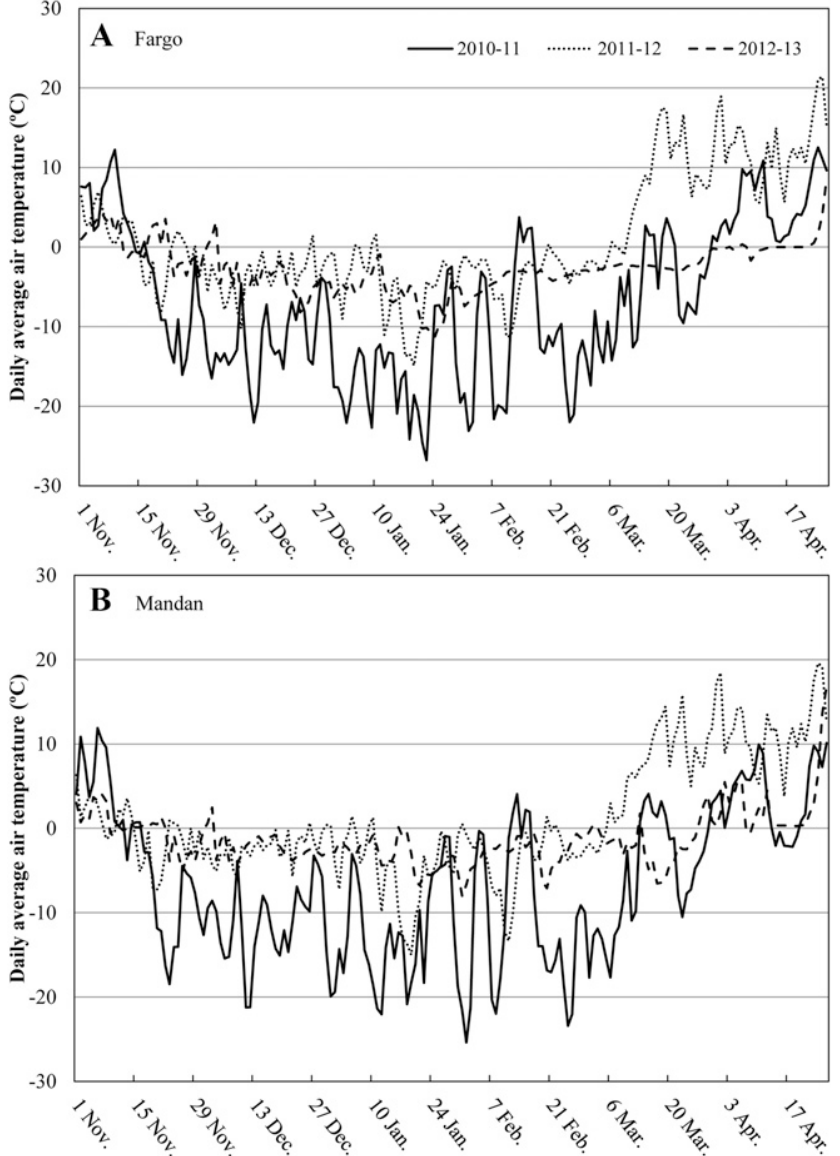

Fig. 2. Daily average air temperature from Nov. to Apr. 2010-13 at Fargo, ND (A) and Mandan, ND (B). Air temperatures were recorded with data loggers (model no. EL-USB-1; Lascar Electronics, Salisbury, UK); $\left(1.8 \times{ }^{\circ} \mathrm{C}\right)+32={ }^{\circ} \mathrm{F}$.
(10) and Mandan (9.2) (see page 6 for rating parameters). A change in rank indicates a relative difference in the order of spring vigor from high to low between the two sites. 'Pawnee' big bluestem also had an acceptable level of vigor at Fargo (6.3) and Mandan (9.5). However, big bluestem was acceptable at Mandan (10) but not Fargo (5). 'Narrow Leaf' maidengrass survived at both sites but had spring vigor rates lower than acceptable at Fargo and Mandan $(0.8$ at both locations). The other 11 grasses died at one or both sites and had spring vigor rates at less than acceptable levels.

Fall QUALITY. A significant $(P \leq$ $0.05)$ grass $\times$ location interaction was observed in fall quality between the Fargo and Mandan sites (Table 3 ). There was a change in rank with silver banner grass, 'Pawnee' big bluestem, and big bluestem (species). 'Pawnee' big bluestem had an acceptable fall quality rate at the Mandan site (6.5) but none of the aforementioned grasses had an acceptable fall quality rate at either site. 'Narrow Leaf' maidengrass survived at both sites but had fall quality rates lower than acceptable at Fargo (1.5) and Mandan (0.5). The other 11 grasses died at one or both sites and had fall quality rates at less than acceptable levels.

Fall Leaf Length. Silver banner grass produced the longest leaves with an average length of $119.0 \mathrm{~cm}$ which was significantly greater than 'Pawnee' big bluestem $(90.0 \mathrm{~cm})$ (Table 4). Giant miscanthus produced an average length of $80.0 \mathrm{~cm}$, which was significantly similar to 'Pawnee' big bluestem and big bluestem (species)

Table 6. Number of days that reached $35^{\circ} \mathrm{C}\left(95.0^{\circ} \mathrm{F}\right)$ or higher per mo. (NOD35) and monthly precipitation totals (MPT) during ornamental grass evaluations at the Fargo and Mandan, ND test sites. ${ }^{\mathrm{z}}$

\begin{tabular}{|c|c|c|c|c|c|c|c|c|c|c|}
\hline \multirow[b]{2}{*}{$\underline{Y r}$} & \multicolumn{2}{|c|}{ May } & \multicolumn{2}{|c|}{ June } & \multicolumn{2}{|l|}{ July } & \multicolumn{2}{|c|}{ August } & \multicolumn{2}{|c|}{ September } \\
\hline & NOD35 (d) & $\begin{array}{c}\text { MPT } \\
(\mathrm{mm})^{\mathrm{y}}\end{array}$ & NOD35 (d) & $\begin{array}{l}\text { MPT } \\
(\mathrm{mm})\end{array}$ & NOD35 (d) & $\begin{array}{l}\text { MPT } \\
(\mathrm{mm})\end{array}$ & NOD35 (d) & $\begin{array}{l}\text { MPT } \\
(\mathrm{mm})\end{array}$ & NOD35 (d) & $\begin{array}{l}\text { MPT } \\
(\mathrm{mm})\end{array}$ \\
\hline & & & & & Fargo & & & & & \\
\hline 2010 & 0 & 68.1 & 0 & 86.1 & 0 & 110.0 & 0 & 67.8 & 0 & 151.4 \\
\hline 2011 & 0 & 109.7 & 1 & 100.8 & 1 & 100.0 & 0 & 72.6 & 0 & 4.1 \\
\hline 2012 & 0 & 43.4 & 0 & 56.9 & 3 & 30.0 & 0 & 20.8 & 0 & 1.3 \\
\hline 2013 & 0 & 141.0 & 0 & 199.4 & 0 & 26.0 & 0 & 12.2 & 0 & 106.4 \\
\hline & & & & & Mandan & & & & & \\
\hline 2010 & 0 & 85.1 & 0 & 91.9 & 0 & 63.5 & 2 & 51.6 & 0 & 111.8 \\
\hline 2011 & 0 & 82.6 & 0 & 91.7 & 0 & 167.9 & 0 & 71.1 & 0 & 26.4 \\
\hline 2012 & 0 & 45.7 & 0 & 60.2 & 4 & 52.8 & 1 & 45.7 & 1 & 0.8 \\
\hline 2013 & 0 & 222.5 & 0 & 112.3 & 0 & 22.1 & 4 & 37.3 & 0 & 98.6 \\
\hline
\end{tabular}

${ }^{\mathrm{z}}$ Air temperatures and precipitation totals provided by North Dakota Agricultural Weather Network, 2015

${ }^{\mathrm{y}} 1 \mathrm{~mm}=0.0394$ inch. 
$(70.0 \mathrm{~cm})$. Big bluestem (species) produced an average leaf length significantly equivalent to 'Silver Feather' maidengrass $(54.0 \mathrm{~cm})$. Both produced an average leaf length significantly longer than 'Blondo' maidengrass $(29.0 \mathrm{~cm})$, 'Narrow Leaf' maidengrass $(23.0 \mathrm{~cm})$, and 'Grosse Fontaine' maidengrass $(13.0 \mathrm{~cm})$. The remaining seven grasses died before leaf length measurements were taken.

FALl Flower height. The three tallest grasses after anthesis were 'Pawnee' big bluestem with an average fall flower height of $133.0 \mathrm{~cm}$ followed by big bluestem (species) $(127.0 \mathrm{~cm})$ and silver banner grass $(125.0 \mathrm{~cm})$ (Table 5 ). All three grasses were significantly equivalent to each other and significantly taller than 'Silver Feather' maidengrass $(56.0 \mathrm{~cm}$ ), which was significantly taller than 'Narrow Leaf' maidengrass $(32.0 \mathrm{~cm})$ and 'Blondo' maidengrass $(27.0 \mathrm{~cm})$. 'Narrow Leaf' and 'Blondo' maidengrass were significantly equivalent to each other. Only one 'Grosse Fontaine' maidengrass replicate survived by the conclusion of the trial at the Fargo site (Table 1), but did not produce any flowers. All giant miscanthus replicates survived the duration of the trial at the Fargo site but only one replicate survived by the end of the second winter at the Mandan site. None of the surviving giant miscanthus flowered at either location. The remaining seven grasses died before flower height measurements were taken.

In summary, the low-input management regime in addition to the cold soil temperatures (Fig. 1) and air temperatures (Fig. 2) during winter had an effect on plant growth, performance, and survival. Soil temperatures remained at or slightly below $0{ }^{\circ} \mathrm{C}$ from December through February at the Fargo location and from November through February at the Mandan site. The lowest soil temperature recorded at the Fargo location was $-8.6{ }^{\circ} \mathrm{C}$, which occurred on 24 Jan. 2013. The lowest soil temperature recorded at the Mandan location was $-6{ }^{\circ} \mathrm{C}$, which occurred on 1 Feb. 2013. Some silver banner grass and maidengrass cultivars can tolerate soil temperatures as low as $-6.7^{\circ} \mathrm{C}$. However, if soil temperatures drop gradually, miscanthus rhizomes may survive at soil temperatures as low as $-14{ }^{\circ} \mathrm{C}$ (Piexoto et al., 2015). Other adverse growing conditions such as high summer air temperatures coupled with low precipitation may have had a detrimental effect on survival. The optimal growth temperature range for warm-season ornamental grasses is 27 to $35^{\circ} \mathrm{C}$ (Trinklein, 2006). The month with the most days that exceeded a $35{ }^{\circ} \mathrm{C}$ air temperature at the Fargo site was July 2012 with three. The total precipitation that month was $30 \mathrm{~mm}$. The months with the most days that exceeded a $35^{\circ} \mathrm{C}$ air temperature at the Mandan site occurred during July 2012 and Aug. 2013 , each with four. The total precipitation was 52.8 and $37.3 \mathrm{~mm}$, respectively, during July 2012 and Aug. 2013 (NDAWN, 2015) (Table $6)$. It is highly unlikely that the summer air temperatures that exceeded the optimal growth range were the primary reason for poor growth and survival during this study.

Our results indicated that silver banner grass was the most tolerant grass to the low-management inputs and cold winter conditions. All silver banner grass replicates survived at both locations and scored the highest spring and fall quality ratings. Silver banner grass also had the greatest average fall leaf length and significantly just as tall as 'Pawnee' big bluestem and big bluestem (species) after anthesis. Although several grasses performed well in this cold-hardy, low-input trial, silver banner grass proved to be the most durable, tall ornamental grass species for use in the upper midwestern United States. Its average leaf length and flower height, which exceeded 118 and $124 \mathrm{~cm}$, respectively (Tables 5 and 6) would make this grass an effective species for screening or creating privacy. However, its aggressive rhizomatous growth habit precludes its use in most landscapes unless an effort is made to contain its invasive nature. Given its limited acceptance as a landscape selection, silver banner grass may be a potential source of biomass feedstock for ethanol producers in the upper midwestern United States. Researchers are interested in developing cost-effective cultural methods to grow various miscanthus grasses for biofuel production (Bansal et al., 2013; Heaton et al., 2008; Scurlock 1999; Wang et al., 2012) and silver banner grass may be a suitable species for testing.

Many of the grasses evaluated in this study were grown outside of their cold hardiness range (Table 1 )
(USDA hardiness zone ratings for the grasses used in this study were provided by the following sources: Bluebird Nursery, 2015; Kurt Bluemel, Inc., 2015; Missouri Botanical Garden, 2015; Wilson, 2011). Therefore, their inability to survive was not unexpected. However, one replicate of the 'Grosse Fontaine' maidengrass, rated as a zone 5 grass was able to survive the entire 3 -year study at the Fargo location.

Many cold hardiness studies have been conducted on native and ornamental grasses. However, we are not aware of any that combined cold hardiness with a low-input regime. Many of the grasses that failed may have survived if they received the proper care such as supplemental irrigation, light fertilization, or soil cultivation if needed. Although it cannot be stated with certainty that the grasses that failed to survive actually died of cold exposure during winter, drought stress during summer, or a combination of both, any new data that prove the ability of ornamental grasses to survive a low-input regime in the upper midwestern United States may encourage nurseries and garden center owners in the region to carry a wider selection of ornamental grasses in their inventory.

\section{Literature cited}

Bansal, A., P. Illukpitiya, S.P. Singh, and F. Tegegne. 2013. Economic competiveness of ethanol production from cellulosic feedstock in Tennessee. Renew. Energy 59:53-57.

Bertholdsson, N.O. 2005. Early vigour and allelopathy: Two useful traits for enhanced barley and wheat competitiveness against weeds. Weed Res. 45:94-102.

Bluebird Nursery. 2015. Products. 15 Oct. 2015. <https://www.bluebirdnursery. com/Products.asp $>$.

Carmer, S.G., W.E. Nyquist, and W.M. Walker. 1989. Least significant differences for combined analyses of experiments with two-or-three factor treatment designs. Agron. J. 81:665-672.

Fech, J.C., D.T. Lindgren, A.M. Streich, and K.A. Todd. 2007. Ornamental grasses for Nebraska landscapes. Univ. Nebraska. Coop. Ext. Serv. Bul. G1691.

Fry, J. and B. Huang. 2004. Applied turfgrass science and physiology. Wiley, Hoboken, NJ.

Greenlee, J. and D. Fell. 1992. Encyclopedia of ornamental grasses. Rodale, Emmaus, PA. 
Hamdi, B.A., M.O. Inderjit, M. Olofsdotter, and J.C. Streibig. 2001. Laboratory bioassay for phytotoxicity: An example from wheat straw. Agron. J. 93:43-48.

Heaton, E.A., F.G. Dohleman, and S.P. Long. 2008. Meeting U.S. biofuel goals with less land: The potential of Miscanthus. Glob. Change Biol. 14:2000-2014.

Kalb, T. 2009. Perfect for today's landscapes: Ornamental grasses. Dakota Gardner $2(3): 1,7$.

Koppler, M.R., I. Kowarik, N. Kuhn, and M. von der Lippe. 2014. Enhancing wasteland vegetation by adding ornamentals: Opportunities and constraints for establishing steppe and prairie species on urban demolition sites. Landsc. Urban Plan. 126:1-9.

Kurt Bluemel, Inc. 2015. Grasses. 15 Oct. 2015. <http://www.kurtbluemel.com/ botanical/grasses_a.html\#>.

Love, S.L. 2012. Mature sizes of ornamental grasses. 12 Dec. 2015. <http://web. cals.uidaho.edu/idahogardens/2012/08/ mature-size-of-ornamental-grasses $/>$.

Love, S.L. and T. Salaiz. 2009. Ornamental grasses for Idaho landscapes. 12 Dec. 2015. <http://www.cals.uidaho. edu/edcomm/pdf/CIS/CIS1161.pdf $>$.

McIntosh, M.S. 2015. Can analysis of variance be more significant? Agron. J. 107:706-715.

Meyer, H.M. 2012. Ornamental grasses for cold climates: A guide to selection and management. Univ. Minnesota Coop. Ext. Serv. Bul. 06411.

Meyer, H.M., D.B. White, and H. Pellett. 2008. Ornamental grasses for Minnesota. Univ. Minnasota Coop. Ext. Serv. Bul. FS-06422.

Missouri Botanical Garden. 2015. Plant finder. 15 Oct. 2015. <http://www. missouribotanicalgarden.org/plantfinder/ plantfindersearch.asp $>$.

Moore, K.J. and P.M. Dixon. 2015. Analysis of combined experiments revisited. Agron. J. 107:763-771

Morris, K.N. and R.C. Shearman. 2006. NTEP turfgrass evaluation guidelines. 1 July 2010. <http://www.ntep.org/ reports/ratings.htm\#quality $>$.

Nakano, H., S. Morita, H. Shigemori, and K. Hasegawa. 2006. Plant growth inhibitory compounds from aqueous leachate of wheat straw. Plant Growth Regulat. 48:215-219.

U.S. Department of Agriculture (USDA). 1998a. Tally series. 23 Sept. 2015. <https://soilseries.sc.egov.usda. gov/OSD_Docs//T/TALLY.html>.

U.S. Department of Agriculture (USDA). 1998b. Parshall series. 23 Sept. 2015. <https://soilseries.sc.egov.usda.gov/ OSD_Docs //P/PARSHALL.html>.

U.S. Department of Agriculture (USDA). 1999. Telfer series. 23 Sept. 2015. $<$ https://soilseries.sc.egov.usda.gov/ OSD_Docs//T/TELFER.html>.
U.S. Department of Agriculture (USDA). 2015. Fargo series. 23 Sept. 2015. <https://soilseries.sc.egov.usda.gov/ OSD_Docs //F/FARGO.html>.

North Dakota Agricultural Weather Network. 2015. Monthly and daily weather data. 3 Nov. 2015. <https://ndawn.ndsu. nodak.edu/weather-data-monthly.html>.

Piexoto, M., P.C. Friesen, and R.F. Sage. 2015. Winter cold-tolerance thresholds in field-grown Miscanthus hybrid rhizomes. J. Expt. Bot. 66:4415-4425.

Plowes, C. 2012. Ornamental grasses: An essential guide. Crowood Press, Ramsbury, UK.

Scurlock, J.M.O. 1999. Miscanthus: A review of European experience with a novel energy crop. U.S. Dept. Energy ORLN/TM-13732.

Trinklein, D.H. 2006. Ornamental grasses. Missouri Univ. Coop. Ext. Serv. Bul. G 6661 Sept. 2006.

Wang, D., M.W. Maughan, J. Sun, X. Feng, F. Miguez, D. Lee, and M.C. Dietze. 2012. Impact of nitrogen allocation on growth and photosynthesis of miscanthus (Miscanthus $\times$ giganteus). Glob. Change Biol. Bioenergy 4:688-697.

Wilson, C.R. 2011. Ornamental grasses. Colorado State Univ. Coop. Ext. Serv. Bul. 7.232. 27 Oct. 2015. <http://extension. colostate.edu/topic-areas/yard-garden/ ornamental-grasses-7-232/>. 